Teologia i Moralność, Volumen 13(2018), numer 1(23)

doi: $10.14746 /$ tim.2018.23.1.8

\author{
ANDRZEJ MUSZALA \\ Uniwersytet Papieski Jana Pawła II w Krakowie \\ Wydział Nauk Społecznych
}

\title{
Sposoby rozwiązywania małżeńskich kwestii „nieregularnych” w Kościele starożytnym i wczesnośredniowiecznym
}

Kościół pierwszych wieków od samego początku przykładał wielką wagę do kwestii trwałości związku małżeńskiego. Czynił to, opierając się na zasadzie nierozerwalności małżeństwa zawartej w Ewangelii. Celem tej nauki była troska o dobro małżeństwa i rodziny (dzieci), wzrost duchowy małżonków oraz odcięcie się od swobody obyczajów charakterystycznej dla moralności pogańskiej. Starożytny Rzym nie narzucał ani wierności małżonkom, ani wstrzemięźliwości nieżonatym. Dlatego zgłaszający się do chrztu dorośli mieli obowiązek uregulować swoją sytuację małżeńską: zobowiązać się do monogamii i wierności małżeńskiej (por. Hipolit Rzymski 1976, 15, 16). Zasad tych przestrzegano bardzo konsekwentnie i jednoznacznie. Zdarzały się jednak upadki, najczęściej wskutek niedochowania wierności małżeńskiej przez jedną ze stron. Chrześcijanie od Aleksandrii po Lyon musieli zmierzyć się z następującym problemem: Czy osoby wchodzące w powtórny związek mogą uzyskać pojednanie z Bogiem i Kościołem oraz czy można dopuścić je do Eucharystii? Była to kwestia analogiczna do problemu ponownej integracji z Kościołem tych ochrzczonych, którzy w czasie prześladowań dokonali apostazji. Niektórzy chrześcijanie - zwłaszcza w Azji - odmawiali im takiej możliwości, głosząc rygorystyczną zasadę absolutnej, dożywotniej ekskomuniki (por. Euzebiusz z Cezarei 1924, V, 2, 5); inni zajmowali stanowisko przeciwne, uznając, że ludzka słabość winna mieć otwartą drogę do pojednania się z nieskończenie dobrym Bogiem, choć przecież wyparcie się Jezusa naznaczało kogoś na całe życie. Jeżeli chodzi o przypadki osób wchodzących w drugi związek, analizowano dogłębnie, która ze stron jest winna rozpadu małżeństwa (ocenę utrudniał fakt, że zawarcie małżeństwa jest aktem dwóch osób i wina może rozkładać się nierównomiernie), czy żałuje swego czynu, 
czy da się powrócić do stanu poprzedniego, nie wyrządzając krzywdy potomstwu powstałemu z nowego związku. Odwoływano się także do rozstrzygnięć z listów nowotestamentalnych (przywileju Pawłowego lub Piotrowego) oraz do zapisu z Ewangelii św. Mateusza: „Każdy, kto oddala swoją żonę - poza wypadkiem nierządu - naraża ją na cudzołóstwo; a kto by oddaloną wziął za żonę, dopuszcza się cudzołóstwa" (Mt 5,31-32).

Teologowie starożytni zastanawiali się, co oznacza „nierząd” (gr. porneia), który miałby stanowić wyjątek ustanowiony przez samego Jezusa. Czy w takim przypadku możliwe byłoby dopuszczenie do Komunii Świętej niektórych osób żyjących w ponownym związku? Rozstrzygnięcia tej kwestii zawarte zostały głównie w Kanonach starożytnego Kościoła oraz - w późniejszym okresie w Penitencjałach (Księgach pokutnych). W niniejszym artykule dokonamy ich prezentacji, pomijając te, które przez swoją niejednoznaczność budzą wątpliwości, czy chodzi o powtórne małżeństwo czy też o przypadek separacji.

\section{Kanony starożytnego Kościoła}

Najważniejszym dokumentem dotyczącym omawianej przez nas kwestii są Kanony starożytnego Kościoła, spośród których najliczniejsze i najobszerniejsze są Kanony św. Bazylego Wielkiego (330-379; Kanony św. Bazylego 2009, s. 32-60). Odnajdujemy w nich między innymi następujące rozstrzygnięcia:

4. O tych, którzy zawierają związek małżeński trzy lub więcej razy.

Wobec tych, którzy zawierają małżeństwo trzy lub więcej razy, ojcowie ustanowili taki sam przepis, jak wobec digamistów: jeden rok [pokuty], chociaż inni żądali dla nich dwóch lat; tych, którzy zawierają małżeństwo po raz trzeci, wykluczają ze wspólnoty na trzy, a często i na cztery lata. Takich związków nie nazywają już małżeństwem lecz poligamią albo raczej umiarkowaną rozpustą. [Dlatego też Pan tak powiedział do Samarytanki, która miała kolejno pięciu mężów: „Ten, którego masz teraz, nie jest twoim mężem"]. Ci bowiem, którzy przekroczyli miarę dwóch małżeństw, nie zasługują na miano męża lub żony. Zgodnie ze zwyczajem, dla tych, którzy zawarli trzecie małżeństwo, przyjęliśmy pięcioletnią ekskomunikę nie na podstawie kanonów, lecz wedle praktyki naszych poprzedników. Nie należy jednak zupełnie wykluczać ich z Kościoła, lecz przez dwa lub trzy lata włączyć ich do grona słuchających, a potem pozwolić im na obecność wśród wiernych, ale bez udziału w komunii; dopiero wówczas, gdy ukażą owoc nawrócenia, można ich dopuścić do pełnej wspólnoty (tamże, s. 36).

W powyższym zapisie Bazyli wyraża swoje ubolewanie z powodu rozpadu niektórych małżeństw; tych, którzy trzykrotnie lub więcej razy weszli w nowy 
związek, określa jako osoby dopuszczające się „poligamii” lub „umiarkowanej rozpusty"; ich związku nie nazywa małżeństwem. Jako biskup i pasterz diecezji pragnie jednak ratować od zguby nawet i takich, jeśli tylko żałują swego postępowania. Daje im szansę powrotu do wspólnoty Kościoła, wyznaczając pięcioletnią pokutę. Traktuje ten czas jako okazję do ponownej formacji pokutującego człowieka, by na nowo przygotować go do życia według wymogów Ewangelii.

\section{O cudzołożnych mężczyznach i kobietach.}

Wypowiedź Pana o nierozerwalności małżeństwa poza przypadkiem nierządu logicznie rzecz biorąc odnosi się zarówno do mężczyzn, jak i do kobiet. Zwyczaj jednak jest inny: drobiazgowa skrupulatność wypowiedzi dotyczy jedynie kobiet [otóż Apostoł mówi: „Kto łączy się z nierządnicą, stanowi z nią jedno ciało”, Jeremiasz zaś powiada, że ,jeśli kobieta poślubi innego mężczyznę, nie wróci do swego męża, lecz zbezczeszczona uznana będzie za zbezczeszczoną”, oraz: „Kto trzyma cudzołożną, głupi jest i bezbożny"]. Zwyczaj natomiast nakazuje żonom pozostawać przy swoich mężach, nawet jeśli są cudzołożni i rozpustni. Nie wiem zatem, czy można nazywać cudzołożnicą kobietę, która żyje z mężczyzną opuszczonym przez swą żonę. Oskarżenie dotyczy w takim przypadku tej, która porzuciła męża, zależnie od powodu zerwania małżeństwa (tamże, s. 38).

Z powyższego zapisu można wyciągnąć kilka wniosków. Po pierwsze, inna jest sytuacja kobiety, która się rozwodzi, od tej, która poślubia opuszczonego mężczyznę; ta pierwsza, zwłaszcza, jeśli czyni to z premedytacją, winna jest rozpadowi małżeństwa. Po drugie, z zapisu przebija zasada nierównego traktowania kobiet i mężczyzn. Mężczyźni są tu uprzywilejowani: nawet jeśli dopuścili się zdrady, żony powinny pozostać im wierne; zasada ta nie działa jednak w drugą stronę. Można podejrzewać, że w zapisie tym przebija przyjmowany a priori w starożytności pogląd o wyższym statusie mężczyzny niż kobiety. Mężczyzna jako pater familias miał o wiele większe prawa od swojej żony; według prawa rzymskiego mógł ją oddalić z różnych powodów. W świetle chrześcijańskim zasada ta jawi się jako niesprawiedliwy relikt moralności pogańskiej, który, niestety, został zasymilowany przez wielu ojców Kościoła. Skoro wymaga się wierności żony wobec cudzołożnego męża (który dodatkowo winien żałować za swój czyn i przyjąć odpowiednią pokutę), to takie samo wymaganie winno być stawiane mężczyźnie. Po trzecie, Bazyli waha się, czy „można nazywać cudzołożnicą kobietę, która żyje z mężczyzną opuszczonym przez swą żonę". Z jednej strony zasada nierozerwalności małżeństwa nakazywałaby kobiecie nie wchodzić w taki związek, z drugiej - skoro już do tego doszło - Bazyli obawia się skrzywdzić taką kobietę, bo jest świadomy, że dla niej jest to pierwszy związek. Przebija tu także pewna pokora biskupa kapadockiego, który przyznaje się do swojej niewiedzy, jakie powinno być rozwiąza- 
nie danego kazusu, i pozostawia tę kwestię do dalszej dyskusji. W tym samym punkcie czytamy: „Kobieta opuszczająca męża jest cudzołożnicą, jeżeli wiąże się z innym mężczyzną, natomiast opuszczony mąż jest usprawiedliwiony, i kobieta, która z nim współżyje nie podlega potępieniu" (tamże, s. 39).

W zapisie tym zakłada się, że inna jest sytuacja osoby opuszczonej niż tej, która opuszcza współmałżonka w celu zawarcia nowego związku. Osoba opuszczona (można podejrzewać także, że niewinna rozpadowi małżeństwa) jest usprawiedliwiona, choć Bazyli nie określa, czy może przystępować do Komunii Świętej. Kobieta, która poślubia opuszczonego mężczyznę, nie dopuszcza się cudzołóstwa.

22. O tym, kto zatrzymuje przy sobie porwaną, poślubioną lub nie.

[...] Tego jednak, kto przetrzymuje kobietę, którą uwiódł albo zdobył przemocą lub podstępem, należy koniecznie ukarać jak za nierząd. Za nierząd zaś wyznaczono karę czterech lat pokuty. W pierwszym roku [pokutnicy] mają być wyłączeni z modlitw i płakać przy drzwiach kościoła; w drugim roku można ich dopuścić do słuchania; w trzecim do czynienia pokuty; w czwartym do udziału w zgromadzeniach ludu, ale bez uczestnictwa w ofierze, i dopiero wtedy można im zezwolić na przyjmowanie komunii (tamże, s. 44-45).

Bazyli potwierdza ustaloną wcześniej w Kościele karę za nierząd: cztery lata ekskomuniki. Gdyby mężczyzna winny uwiedzenia kobiety żałował swego czynu, może wejść na drogę integracji z Kościołem po czteroletniej, ponownej formacji do życia według Ewangelii.

\section{O kobiecie, która bez powodu opuściła męża.}

W przypadku męża opuszczonego przez żonę należy brać pod uwagę powód opuszczenia. Jeśli okaże się, że żona opuściła go bez dostatecznego powodu, on zasługuje na wybaczenie, ona zaś podlega karze. Wybaczenie pozwala mu uczestniczyć we wspólnocie Kościoła (tamże, s. 48).

W zapisie tym ponownie spotkamy postulat rozeznawania sytuacji; w ocenie należy brać pod uwagę powód opuszczenia współmałżonka. Jeśli mężczyzna nie jest winny rozpadowi małżeństwa, może uczestniczyć w życiu wspólnoty (może także przystępować do Komunii Świętej). Nie jest jednak określone, czy może wstąpić w nowy związek małżeński.

77. O tych, którzy porzucają swe żony i biorą sobie inne.

Kto porzuca żonę, z którą zawarł legalny związek małżeński, i bierze sobie inną, na mocy wyroku Pana podlega karze za cudzołóstwo. Nasi ojcowie ustalili, że 
winni takiego grzechu mają przez rok opłakiwać swą przewinę, przez dwa lata słuchać, przez trzy lata leżeć krzyżem, w siódmym roku asystować na zgromadzeniach wiernych, i dopiero wtedy mogą być dopuszczeni do ofiary, jeśli ze łzami okażą skruchę (tamże, s. 57).

W powyższym kanonie mamy do czynienia $\mathrm{z}$ typowym, zawinionym przypadkiem zerwania małżeństwa w celu zawarcia nowego związku. Bazyli nazywa to cudzołóstwem. Kto by tak czynił, pozbawia się możliwości pełnego uczestnictwa w ofierze mszy świętej, także możliwości przyjmowania Komunii Świętej. Gdyby jednak człowiek ów żałował, istnieje możliwość dla niego siedmioletniej pokuty. Ojciec kapadocki dość szczegółowo określa, co ta osoba powinna czynić w poszczególnych latach, by móc zostać ponownie włączona do wspólnoty Kościoła i uczestniczyć w pełni w ofierze eucharystycznej. Zakres siedmioletniej ekskomuniki dla osób zrywających małżeństwo, a następnie nawracających się i podejmujących za ten czyn odpowiednią pokutę, był w kilku kolejnych stuleciach najczęściej stosowanym zwyczajem, jaki przyjęto w Kościele powszechnym. Na przykład Synod w Konstantynopolu w roku 692 potwierdził siedmioletnią pokutę dla osób winnych rozpadowi małżeństwa i żyjących w powtórnym związku (pod warunkiem szczerej skruchy za swój czyn), powtarzając dosłownie kanon 77. św. Bazylego. Czas ten traktowano jako okres przeznaczony na ponowną formację człowieka do życia według wymagań Ewangelii.

Do kanonów Kościoła starożytnego weszły także zapisy z Listu Bazylego do Diodora z Tarsu (List Bazylego do Diodora z Tarsu 2009, s. 60-63). W związku z interesującą nas tutaj kwestią czytamy:

87. [Ja zaś wobec każdego człowieka, który chce wstąpić w związek małżeński składam świadectwo, że „przemija postać tego świata i czas jest krótki, niechaj więc ci, którzy mają żony, tak żyją, jakby byli nieżonaci”. Jeśli zaś ktoś powoła się na zdanie: „Rośnijcie i rozmnażajcie się”, wyśmieję go, bo nie widzi, w jak różnych okolicznościach te zdania były wypowiadane.] Powtórne małżeństwo jest lekarstwem przeciwko nierządowi, a nie lekiem na rozwiązłość. „Jeżeli nie mogą zapanować nad sobą, niech się żenią”, mówi apostoł, a nie: „niechaj zawierając małżeństwo przekraczają Prawo" (tamże, s. 63).

Ten dość dziwny, na pierwszy rzut oka, zapis zawiera ważną informację: lepiej jest człowiekowi wejść w drugi związek małżeński (człowiek uznany jest wówczas za „rozwiązłego”), niż żyć bez związku, cudzołożąc (w takim przypadku człowiek dopuszcza się „nierządu”). Słusznie Bazyli uważa, że najgorsza jest sytuacja, gdy ktoś potajemnie cudzołoży z kobietą, żyjąc w związku ze swoją prawowitą małżonką. Zapis ten jest istotny także w czasach współczesnych. Zdarza się niejednokrotnie, że jakaś osoba pozostaje ze 
współmałżonkiem (-ką), a równocześnie zdradza go (ją), prowadząc podwójne życie. Byłoby wówczas wielką niesprawiedliwością, gdyby miała ona możliwość korzystania z sakramentów (pokuty i Eucharystii), podczas gdy osoba żyjąca $\mathrm{w}$ drugim związku nie. Ta druga przynajmniej postępuje w prawdzie, podczas gdy ta pierwsza nie tylko dopuszcza się zdrady, ale dodatkowo oszukuje współmałżonka, całą wspólnotę Kościoła i Boga.

Podsumowując starożytne teksty kanonów traktujące o osobach żyjących w związkach nieregularnych, można wyciągnąć kilka wniosków:

- Starożytni ojcowie zdecydowanie potępiali jakiekolwiek formy zrywania jedności małżeńskiej. Według zamysłu Jezusa mąż i żona stanowią jedno ciało, a ich związek jest nierozerwalny aż do śmierci. „Co Bóg złączył, tego człowiek niech nie rozdziela" - to norma przewidziana dla wszystkich chrześcijan.

- Równocześnie, znając ludzką słabość, ojcowie Kościoła próbowali zaradzić w sytuacji, kiedy do rozpadu małżeństwa jednak doszło, gdy człowiek wykazywał żal za swój czyn i pragnął wrócić do wspólnoty z Jezusem i Kościołem. Zazwyczaj wyznaczano mu siedmioletnią pokutę, która równocześnie była formą reintegracji z Kościołem. Wbrew pozorom nie była to pokuta łatwa ani krótka. Okres siedmiu lat w praktyce oznaczał długi proces ponownego formowania się do dojrzałego chrześcijaństwa. Jednocześnie uważano, że dożywotnie pozbawienie kogoś możliwości przyjmowania Komunii Świętej jest niepedagogiczne: człowiek taki traciłby ducha, co stanowiłoby niebezpieczeństwo popadnięcia w kolejne grzechy. „Skoro nie ma dla mnie nadziei, to po co w ogóle mam żyć uczciwie i dobrze?" - mógłby powiedzieć. Ojcowie starożytni byli świadomi, że dożywotnia ekskomunika odbiera sens wszelkiemu nawróceniu i dążeniu do zmiany swojego postępowania. Dlatego zwykle ograniczali czas odsunięcia od sakramentów, jeśli grzesznik okazywał skruchę i wolę poprawy. Najdłuższe ekskomuniki trwały dziesięć lat (w przypadku zabójstwa i aborcji). Z reguły unikano ekskomunik dożywotnich.

- Ojcowie Kościoła podejmowali próbę wniknięcia w zapisy zawarte w Mt 5,31-32 oraz Mt 19,9, które zawierały wyjątek „nierządu” (gr. porneia) sformułowanego przez Jezusa. Zwykle pod tym terminem rozumieli zdradę małżeńską, która była nie tylko wielką krzywdą wyrządzoną współmałżonkowi (-ce), ale wręcz czynem zrywającym małżeństwo.

- W podejściu do kwestii nieregularnych w małżeństwie daje się zauważyć przewaga spojrzenia soteriologiczno-eschatologicznego nad legalistycznym. To pierwsze było bliższe myśli patrystycznej; nawet najwięk- 
szy grzesznik winien mieć możliwość nawrócenia i powrotu do pełnej komunii z Chrystusem i Kościołem. Starożytni teologowie kierowali się także troską duszpasterską: skoro Dobry Pasterz szuka owiec zaginionych i przyprowadza je do owczarni, należy przyjąć podobną linię postępowania.

Kanony św. Bazylego zostały zebrane przez kanonistów Kościoła wschodniego około VI wieku i powtórzone na synodzie Quinisexta (691-692), gdzie nadano im moc obowiązującego prawa kościelnego.

\section{Księgi pokutne}

Drugim zbiorem tekstów, w których znajdujemy propozycje rozwiązania kwestii nieregularnych w małżeństwie, są Księgi pokutne. Powstały one już w kręgu Kościoła zachodniego, a ich początek datuje się na przełom okresu starożytnego i wczesnego średniowiecza. Cechują się one większą szczegółowością proponowanych rozwiązań. Przykładem jest tu księga Discipulus Umbriensium, która powstała w Italii na przełomie VII i VIII wieku. Czytamy w niej między innymi: ,Jeśli mąż sam się zaprzedał w niewolę poprzez kradzież, rozpustę lub jakikolwiek inny grzech, jeśli wcześniej nie była zamężna, ma prawo po upływie roku pojąć innego męża, a po drugim małżeństwie nie wolno" (Księgi pokutne 2011, s. 156).

W zapisie tym zawarta jest myśl, że nie tylko rozpusta, ale także inne poważne formy niemoralnego prowadzenia się męża (np. kradzież) zrywają jedność małżeńską. Jeśliby te grzeszne zachowania stały się nałogiem (doprowadzając człowieka do wewnętrznego zniewolenia) i życie z kimś takim byłoby nie do zniesienia, wówczas kobieta - jeśli wcześniej nie była zamężna - miała prawo zawrzeć nowy związek. Winna jednak odczekać przynajmniej rok; być może była to forma „oczyszczenia” po poprzednim małżeństwie.

Inny penitencjał Capitula Dacheriana z Galii datowany także na VII/VIII wiek stwierdza:

31. Drugi raz żonaty niech pokutuje jeden rok, w środy i piątki i trzy posty po czterdzieści dni niech się powstrzyma od wina i mięsa, ale bez separacji małżonków (tamże, s. 118).

32. Trzeci raz żonaty i więcej, to znaczy czwarty, szósty i więcej, niech pokutuje siedem lat, w środy i piątki i trzy posty po czterdzieści dni niech się powstrzyma od wina i mięsa, jednak niech nie oddala żony (tamże). 
Powyższe zapisy ukazują pośrednio smutny upadek wierności małżeńskiej w okresie, gdy chrześcijaństwo stało się oficjalną religią w świecie zachodnim we wczesnym średniowieczu. Zdarzały się, niestety, przypadki wielokrotnego zrywania małżeństwa i wchodzenia w nowe związki. Aplikowano wówczas surowe pokuty wraz z siedmioletnią ekskomuniką, jednak nadal unikano dożywotniego odsunięcia od sakramentów. Norma ta została powtórzona w tym samym penitencjale w numerze 107.: „Kto oddaliłby swoją żonę, żeniąc się z inną, niech pokutuje siedem lat" (tamże, s. 125). W przypadku, gdyby grzesznik się nawrócił, żałował za swoje poprzednie niewierności, nie zalecano porzucania ostatniej małżonki, lecz pozostanie jej wiernym.

Zapis numeru 36, traktujący o uprowadzeniu żony, zezwalał na powtórny związek, jeśli mąż nie był $\mathrm{w}$ stanie odzyskać utraconej małżonki; zapis ten został później przyjęty także w innych penitencjałach: „36. Czyją żonę uprowadziłby wróg i nie może jej odzyskać, temu wolno pojąć inną, lepsze to niż rozpusta. Gdyby potem wróciła żona, nie musi jej przyjmować z powrotem, jeśli ma inną, lecz ona sama niech weźmie drugiego męża, jeśli wcześniej miała jednego" (tamże, s. 118).

Z kolei numer 159 Capitula Dacheriana odnosił się do przypadku porzucenia męża przez żonę. W takiej sytuacji porzucony mąż mógł powtórnie się ożenić, jednak za zgodą biskupa. Wcześniej winien on przejść dwuletni okres „oczyszczenia” po pierwszym małżeństwie: „159. Świecki, od którego odeszła żona, za zgodą biskupa po dwóch latach niech weźmie inną" (tamże, s. 130).

Numer 163 Capitula Dacheriana odnosił się do zapisu zawartego w Mt 5,31-32 oraz Mt 19,9, zezwalając na powtórne małżeństwo mężczyzny, jeśli jego żona dopuściła się rozpusty („nierządu”): „163. Jeśli czyjaś żona dopuściłaby się rozpusty, wolno ją oddalić i wziąc inną" (tamże).

W Brytanii obowiązywał Penitencjat św. Egberta arcybiskupa Yorku składający się z pięciu ksiąg pokutnych (VIII w.). W rozdziale 26. znajduje się zapis: „26. [2] Jeśli kobieta odrzuca od siebie swego męża, a następnie nie chce się opamiętać, ani przez pięć lat nie powraca pokój między nimi, mężczyzna za zgodą biskupa może pojąć inną żonę" (tamże, s. 211). W zapisie tym mamy do czynienia po raz pierwszy z przypadkiem trwałego zerwania więzi małżeńskiej; jeśli przez pięć lat nie udaje się przywrócić zgody między małżonkami, wówczas - za przyzwoleniem biskupa - możliwe jest zawarcie drugiego małżeństwa.

W Księdze pokutnej z Merseburga $b$ z terenów Germanii stwierdzono: „31. Niewiasta ma prawo pojąć innego za męża, jeśli jej małżonek odda się w niewolę kradzieży lub nierządu" (tamże, s. 310). Zapis ten jest echem italskiego Discipulus Umbriensium. Stwierdza, że stałe nieprawe zachowanie męża jest podstawą do opuszczenia go i zawarcia drugiego małżeństwa. Po- 
dobne rozstrzygnięcie podawała inna Księga Pokutna Vigilanum z miasta Albelda (ok. 850-900): „89. Żona ma prawo pojąć innego męża, jeśli jej mąż uczynił siebie niewolnikiem z powodu kradzieży lub cudzołóstwa" (tamże, s. 412).

Na początek XI wieku datują się Dekrety Burcharda, biskupa Kościoła w Wormacji. Zapisano w nich między innymi: „V [93]: Czy współżyłeś z siostrą swej żony? Jeśli tak, nie masz żadnej z nich. Jeśli twoja żona nie była świadoma zbrodni, a nie chce się powstrzymywać, może poślubić w Panu, kogo chce. Ty i cudzołożnica pozostajecie bez nadziei na małżeństwo i do końca życia czyńcie pokutę wedle wskazań kapłana" (tamże, s. 386). W rozstrzygnięciu tym po raz pierwszy pojawia się dożywotnia kara ekskomuniki za zdradę małżeńską; podobna sankcja dotyka współuczestniczkę w zdradzie małżeńskiej. Natomiast kara ta nie dotyczy zdradzonej kobiety; jako skrzywdzona uważana była za niewinną i mogła powtórnie wyjść za mąż. Podobne rozstrzygnięcie zawarto w innym zapisie tych samych dekretów: „V [98]: Czy uprawiałeś nierząd ze swoją macochą? Jeśli to uczyniłeś, ani ty, ani ona nie możecie zawrzeć innego małżeństwa. A twój ojciec, gdyby chciał, może wziąć za żonę inną kobietę" (tamże, s. 387).

Dekrety Burcharda cieszyły się w średniowieczu wielką popularnością w wielu krajach europejskich; obowiązywały także na terenie Polski w pierwszych wiekach istnienia Kościoła na naszych ziemiach.

Na podstawie przytoczonych tekstów daje się zauważyć stopniowy upadek obyczajów w kwestii wierności małżeńskiej w miarę upływu wieków. Norma nierozerwalności małżeństwa, tak bardzo przestrzegana przez starożytnych chrześcijan, w średniowieczu uległa pewnej erozji: zdarzały się przypadki wielożeństwa, a nawet skandaliczne zachowania seksualne z członkami własnej rodziny (współżycie ze szwagierką lub macochą). Penitencjały Kościoła zachodniego próbowały rozwiązać te kwestie poprzez nakładanie surowych pokut wobec osób dopuszczających się takich czynów. W obliczu zachowań uwłaczających moralnym zasadom chrześcijańskiej etyki seksualnej zaczęto od XI wieku aplikować także ekskomuniki dożywotnie. W Kościele zachodnim zauważalne jest powolna ewolucja sposobu oceniania kwestii rozpadu małżeństwa od podejścia soteriologiczno-eschatologicznego do podejścia prawnego; być może było to spowodowane rozejściem się Rzymu i Bizancjum. Niektóre rozstrzygnięcia penitencjałów powtarzają się, co świadczy o tym, że tradycja danej wspólnoty lokalnej z biegiem czasu upowszechniała się także w innych obszarach. 


\section{WAYS OF SOLVING MARITAL "IRREGULAR" ISSUES IN THE ANCIENT AND EARLY MEDIEVAL CHURCH}

\section{SUMMARY}

The aim of this article is to present the approach of ancient theologians to the issue of the possibility of allowing certain people who remarry to receive Holy Communion. The conclusions on this matter were discussed on the basis of The canons of the ancient Church and some later Penitential Records. We have omitted texts which, through their ambiguity, raise doubts as to whether it is a remarriage or a case of separation.

The analysis of this material leads to the conclusion that the norm of the indissolubility of marriage, rigorously observed by ancient Christians, in the Middle Ages has undergone some erosion. The penitentiaries of the Western Church tried to solve these issues by imposing severe penances against those who committed such acts, and from the eleventh century, lifelong excommunications were also applied in scandalous cases. The slow evolution of the way of evaluationg the issue of the dissolution of marriage from the soteriological-eschatological approach to the legal approach is also evident. Some resolutions of penitentiaries are repeated, which indicates that the tradition of a given local community over time has also spread in other areas.

Słowa kluczowe: Kanony starożytnego Kościoła; Księgi pokutne; małżeństwo; nierząd

Keywords: The canons of the ancient Church; Penitential records; marriage; prostitution

\section{BIBLIOGRAFIA}

Euzebiusz z Cezarei (1924), Historia kościelna, Pisma Ojców Kościoła t. 3, tłum. A. Lisiecki, Poznań.

Hipolit Rzymski (1976), Tradycja apostolska, 15, 16, http://bazhum.muzhp.pl/media//files/Studia Theologica_Varsaviensia/Studia_Theologica_Varsaviensia-r1976-t14-n1/Studia_Theologica Varsaviensia-r1976-t14-n1-s145-169/Studia_Theologica_Varsaviensia-r1976-t14-n1-s145-169. pdf [dostęp: 21.06.2018].

Kanony św. Bazylego (2009), w: Kanony ojców greckich (tekst grecki i polski) Atanazego i Hipolita (tekst arabski i polski), układ i opracowanie A. Baron i H. Pietras, Kraków, s. 32-60.

Księgi pokutne (tekst łaciński, grecki i polski) (2011), układ i opracowanie A. Baron i H. Pietras, Kraków.

List Bazylego do Diodora z Tarsu (2009), w: Kanony ojców greckich (tekst grecki i polski) Atanazego i Hipolita (tekst arabski i polski), układ i opracowanie A. Baron i H. Pietras, Kraków, s. 60-63. 
Andrzes Muszala - kapłan Kościoła katolickiego, profesor nadzwyczajny w Instytucie Nauk o Rodzinie na Wydziale Nauk Społecznych Uniwersytetu Papieskiego Jana Pawła II w Krakowie. Specjalizuje się w bioetyce społecznej, jego zainteresowania naukowe obejmują m.in. etykę początków życia, opieki duszpasterskiej w służbie zdrowia oraz problemy związane z ludzkim cierpieniem i umieraniem. Autor wielu książek o tematyce bioetycznej, redaktor Encyklopedii bioetyki. 